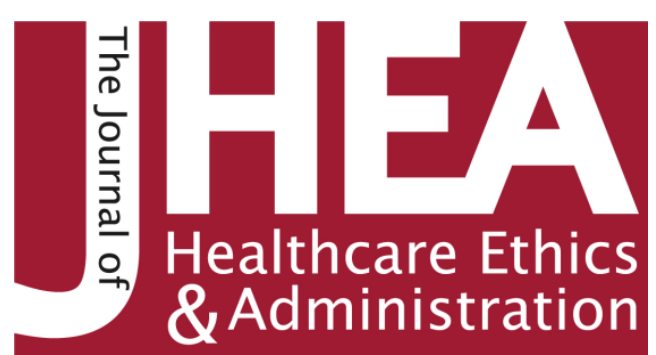

\title{
ARTICLE \\ In Search for the Historical and Philosophical Foundations of Bioethics of Human Dignity and Rights
}

This article appeared originally in The Internet Journal of Catholic Bioethics (Fall 2007)

Y. MICHAEL BARILAN, MD, MA

Sackler School of Medicine, Tel Aviv University, Tel Aviv, Israel.

${ }^{\star}$ Address correspondence to: Sackler School of Medicine, Tel Aviv University, P.O. Box 39040, Tel Aviv 6997801, Israel.

Find this article and more works at www.jheaonline.org

This work is brought to you for free and open access by the Institute of Clinical Bioethics (ICB) at Saint Joseph's University, Philadelphia, PA, U.S.A. It has been accepted for inclusion in The Journal of Healthcare Ethics \& Administration by the editorial board and an authorized administrator of the JHEA. For more information, please contact support@jheaonline.org 
ARTICLE

\title{
In Search for the Historical and Philosophical Foundations of Bioethics of Human Dignity and Rights
}

\author{
This article appeared originally in The Internet Journal of Catholic Bioethics (Fall 2007) \\ Y. MICHAEL BARILAN, MD, MA. \\ Sackler School of Medicine, Tel Aviv University, Tel Aviv, Israel.
}

\section{INTRODUCTION}

The moral language of human dignity plays key roles in contemporary bioethics and bio-law. The UN declaration on human rights and dignity and the Oviedo convention are two examples of international efforts to protect basic human values in the name of "human dignity." Surprisingly, skimpy academic work in bioethics has been published about the meta-ethical, ethical and historical aspects of "dignity and rights." With the exception of Kantian and religious ethics, many books in bioethics do not even have "human dignity" in their indexes.

In this article I wish to make a few steps towards an analytic reconstruction of the idea of "human dignity and rights." In the first section I delineate key narratives of "human dignity." In the second section I explore whether an "ethics of rights and dignity" is to be found in the Bible and other ancient sources. In the third part I offer a theoretical framework for systems of laws and ethics based on the notion of "human dignity and rights." Lastly, I will survey some contemporary challenges facing an ethics of rights and dignity. In this article, I limit my research to the religious and secular streams of thought in the Judeo-Christian traditions, where the ideas of "Imago Dei," "human dignity" and "human rights" have sprouted and developed. Notably, this is a methodological constraint, having no intention to comment on the ethics of other religions and cultures.

\section{META-NARRATIVES OF "HUMAN DIGNITY AND RIGHTS"}

Behind the ethos of "human dignity and rights" we find different historical and hermeneutical meta-narratives. ${ }^{1}$

The Christian religious narrative typically describes three historical stages. ${ }^{2}$ The first is the Biblical notion of man and woman being created in the Image of God. From this are derived special moral duties in respect of human dignity, particularly the protection of human life. A privilege to dominate the natural world and the animal kingdom is also attributed to the special status (dignitas means "status" in Latin) of being human.

During the Enlightenment, the value of human dignity was "decontextualized" from religion and faith in God. But "human dignity" without God seems to lack in moral authority; so following horrors such as the Holocaust and the Gulag, modern sensibilities regarding human dignity and rights have been "re-contextualized" and incorporated in religious thought, as is evident, for example, from the Encyclical, "On the Development of Peoples." Indeed, the post-Vatican II Catholic Church is a world leader in the promotion of human rights, particularly the rights to benefit from basic human goods such as life, healthcare, adequate

\footnotetext{
${ }^{1}$ For a similar scheme, albeit lacking in historical perspective, see M. Häyry, “Another Look at Dignity," Cambridge Quarterly of Healthcare Ethics 13 (2004): 7-14.

${ }^{2}$ R. K. Soulen and L. Woodhead, "The Introduction" in God and Human Dignity, Soulen and Woodhead, eds. H. Roetz and C. Frey (Grand Rapids, MI: Eerdmans, 2006).

${ }^{3}$ Pope John Paul VI, "Encyclical Letter: On the Development of Peoples" (1967), http://www.ewtn.com/library/encyc/p6develo.htm
} 
nutrition, and education. ${ }^{4}$ Protection of bodily integrity from ritual mutilation, torture, capital punishment and even certain forms of surgical "enhancement" is another element in this contemporary ethics of "human dignity." Opposition to the commercialization of human bodies and body-parts and protection of the integrity of the human genome has also been a concern to dignity-oriented ethicists.

Alternative narratives to the religious one exist as well. Liberal thinkers divide history into a period dominated by religion and its agents of oppression and a modern epoch of reason, which is under the signs of universal equality, liberty and fraternity of all people and peoples regardless of race, creed, sexual orientation and personal values. Liberals point out the historical collusions of religion with slavery, torture, colonialism, anti-Semitism and the exploitation of women. Contemporary religious interpretations, particularly Catholic teachings on the "right to life" with regard to abortion, sexuality and the end-of-life, also fall under harsh liberal criticism as being residues of pre-enlightenment oppression of women and of vulnerable people.

A third narrative targets the whole notion of dignity as a fabrication of human self-aggrandizement. Animal-rights activists and "deep environmentalists" call into question the humanist project altogether, be it religious or inspired by secular Enlightenment values. Not only do these critics protest maltreatment of animals, but they also feel that the ethos of human "dominion" propagates an imminent ecological catastrophe.

Scientific disciplines such as "socio-biology" and "neuro-genetics" inspire denial of key elements in the paradigm of "Imago Dei," the existence or the uniqueness of a human moral faculty and free will, for example. Post-structuralist thinkers, such as Foucault and Derrida reject the very tenability of the "human," as metaphysically and ethically coherent concept.

The Christian narrative of human dignity has also been criticized by Judaism and by some "new-age" movements for the doctrine of partial loss and deformation Imago Dei sustained by the Original Sin. According to the official doctrine of the Catholic Church, human dignity is only "rooted" in man's creation in the image of God, but "fulfillment" of human dignity depends on Christian Grace..$^{5}$ As late as in the 19th century encyclical Rerum Novarum, Pope Leo the 13th, attributed dignity to "the Christian character" of people, not to their mere human nature. ${ }^{6}$ Such elliptic formulations do not blend well with the notion that all human beings, regardless of creed, bear dignity wholly, universally and unconditionally. Indeed, as Niebuhr observes, the Renaissance discourse on the dignity of every human individual availed itself of Neoplatonist and Kabbalistic ideas; yet, it cannot be conceived of without Christian inspiration. ${ }^{7}$

Many technophiles seek the religious values of redemption and immortality in a futuristic "post-human" and "techno-sapiens" man, reborn though technologies such as "neuronal implants" and Artificial Intelligence. Christians usually find this very fusion of the "Kingdom of God" with Sci-Fi or "flower age" utopias a genuine threat to "human dignity."

These diversely constructed narratives support opposing moral views in almost every politically-charged debate in bioethics. So, we find "dignity" a pervasive as well as elusive value. It is pervasive in almost all international conventions and declarations on human rights and ethics; yet it is open to so many readings, many are incompatible with each other. Indeed, the pervasiveness, elusiveness, and special appeal of "human dignity" seem to be its undoing. People simply tend to describe their own position as "respectful of human dignity," and the contending opinion, as offensive to human dignity. In the "beginning-of-life" contexts, dignity is heard from conservative and religious circles, whereas in "end-of-life-decision-making," dignity is on the banner of the left-wing liberals.

The rhetoric abuse of human dignity as a value is one reason behind its rising political and lay popularity and its abandonment by many circles of bioethical discourse. As a first step towards the analysis of "human dignity" as a philosophically coherent term and a culturally useful value, I wish to make a distinction between the conceptual structure of ethics of dignity and its specific contents. In order to illustrate my case, I will show in the next section that although virtually all of the specific contents of ethics of dignity are to be found in the Bible and some other ancient sources, they do not contain a conceptual structure of ethics of dignity and rights. In the last section I will delineate what the conceptual structure of an ethics of dignity and rights is like.

In using the word conceptual structure, I do not mean "explicit" or codified as a discrete system of laws or practices. The conceptual structure of dignity and rights is a set of explicit or implicit assumptions operating behind the various items composing

\footnotetext{
${ }^{4}$ R. W. Rousseau, Human Dignity and the Common Good (Westport, CT: Greenwood Press, 2002).

${ }^{5}$ Catechism of the Catholic Church, No. 1700 .

${ }^{6}$ Human dignity "as a human being" is mentioned once in Pope Leo III's encyclical, "On Capital and Labor." http://w2.vatican.va/content/leoxiii/en/encyclicals/documents/hf_l-xiii_enc_15051891_rerum-novarum.html. Possibly, the Pope was also referring to socialist anthropology which cast morally significant "human" in purely material terms, "homo faber."

${ }^{7}$ R. Niebuhr, The Nature and Destiny of Man: a Christian Interpretation: Human Nature (New York: Charles Scribner \& Sons, 1951$), 21$.

${ }^{8}$ A. Jackelen, "The Image of God as Techno Sapiense," Zygon 37 (2002): 289 - 302; Y. Barilan and G. Siegal, "Stem Cell Research: an Israeli Perspective" in Crossing Borders: Cultural, Religious and Political Differences concerning Stem Cell Research, eds. Bender, Hauskeller, Manzei (Münster, Germany: Agenda Verlag, 2005), 293-324.
} 
the content of respect for dignity and rights, infusing them with deeper layers of meanings and propulsing their authoritative momentum.

\section{DIGNITY AND RIGHTS IN THE BIBLE AND OTHER ANCIENT SOURCES.}

A long list of prominent scholars and philosophers believe that the Bible and other ancient sources already contain an elaborate ethics of dignity and rights. Goodman asserts," "What I take to be essential in the idea of rights is the ascription to individuals of positive deserts that are in some sense categorical, concrete, enforceable and determinate." Scholars such as Goodman actually contend that the absence of language of rights in the ancient sources is attributable only to differences in style of expression, and that the ethics of the ancients is probably more protective of human rights than the contemporary instruments of human rights. These scholars marshal a long list of episodes and laws that protect the vulnerable, restrain regal power and defend wellbeing and justice of every person.

The story on the confiscation of Naboth's vineyard by King Ahab (I Kings, 21) is exemplary of protection of private property from the power of the mighty. ${ }^{10}$ Biblical laws are notable for separating the value of life from the value of property; crimes against property are never considered capital, whereas crimes against life are not redeemable by pecuniary compensations and fines. ${ }^{11}$ Such patterns hint towards the existence of values that offer a unifying vision in the spirit of human rights to the long and seemingly arbitrary lists of Biblical laws and morals.

Keeping in mind that as late as the 19th century children were hanged in Britain for the theft of food, Goodman's view on the supremacy of Biblical laws in the protection of human rights seems quite appealing. Such comparative observations might help us ponder whether Biblical and ancient codes of law offer an equally effective alternative to the ethics of dignity and rights. But here we wish to know whether the Bible and the ancient sources offer an ethics of rights and dignity as such. For a profound difference exists between a collage of percepts, laws of values that happen to patch up a blanket of rights and an elaborate and powerful instrument of rights interacting with other laws and moral values.

In my view, although the ancients often proposed values and laws very similar to those now attributed to human dignity and rights, a structure of ethics of dignity and rights is not to be found at least until the 4th century. ${ }^{12}$ Nowhere did the ancients show a concept of human dignity or moral worth that covers a broad area of moral concerns. Moreover, the ancient sources are also rich in examples that go against every possible understanding of human dignity and rights.

In the Bible, the creation of man in the image of God is linked only to bloodshed (Genesis 9:6), and not to other moral dimensions of private and political life. Besides, there is no attempt to reconcile the taboo on homicide with the Biblical long list of capital offenses and the wars against the Canaanites and Amalekites. The story about the famine and the Givonites (II Samuel, 21) is exemplary of fairness in retributive justice, but it is incompatible with any explicit or implicit doctrine of human rights. Stories such as on the vineyard of Naboth are offset by other stories, such as on David and Naval (I Samuel 25).

The systematic nature of Hellenic philosophy and legislation render a more robust vision of rights. Nonetheless, these rights, such as the right to free speech in Athens are all derived from a certain civil status, not from being human. Put in other words, the structure of rights found in Athens captures civil rights only, not the rights of man. Rather, Athenian laws and practice dehumanized foreign "barbarians" and slaves.

Indeed, the ubiquity of slavery in virtually all ancient societies precludes the presence of human rights in any of them. Christianity was a pioneer among occidental religions in its principled objection to slavery. However, Augustine and other Fathers of the Church underlined the distinction between Christian life and worldly life. Slaves were encouraged to accept their lot as slaves while being treated as equals only within religious activities and institutions. ${ }^{13}$ Thomas Aquinas found slavery incompatible with the pristine, natural order in the Garden of Eden, but a necessary element of postlapsarian social life. ${ }^{14}$ The dependence of the

\footnotetext{
${ }^{9}$ L. E. Goodman, Judaism, Human Rights and Human Values (Oxford: Oxford University Press, 1998), 57.

${ }^{10}$ Goodman, 55-6; D. Novak, "Is There a Concept of Individual Right in Jewish Law?" Jewish Law Association Studies 7 (1994): $129-52$.

${ }^{11}$ M. Greenberg, Studies in the Bible and Jewish Thought (Philadelphia, PA: Jewish Publication Society, 1995).

${ }^{12}$ See below.

${ }^{13}$ M. Mary, "Slavery in the Writings of St. Augustine" The Classical Journal 49 (1954): 363-8; P. Garnsey, Ideas of Slavery from Aristotle to Augustine (Cambridge: Cambridge University Press, 1996).

${ }^{14}$ P. E. Sigismund, "Law and Politics" in The Cambridge Companion to Aquinas, eds. N. Kretzman and E. Stump, (Cambridge: Cambridge University Press, 2003), 222; J. Finnis, Aquinas: Moral, Political and Legal Theory (Oxford: Oxford University Press, 1998), 184-5. No doubt the treatment of slaves according to Thomas is significantly more humane than the lot of many serves, let alone New World African slaves. I wish to remind the reader that here we search for a structure of rights, not for the well-being of low class people.
} 
Christian notion of "dignity" on future fulfillment may account for the relative importance of potentiality in the moral status of early manifestations of human life. ${ }^{15}$

Thomas's position illustrates the weakness of the value of Imago Dei in Christian ethics, which focused on the moral anthropology of the fallen rather than natural man. The theological uncoupling of Imago Dei and the dignity of God in man from post-Edenic humanity anticipated the "de-contextualization" of human dignity in Western ethics. In sum, although the Bible and other ancient sources cover substantial moral concerns associated with dignity and rights (perhaps they cover all of them), they lack a conceptual structure of ethics of dignity and rights.

\section{TOWARDS A DEFINITION OF A FORMAL ETHICS OF HUMAN DIGNITY AND RIGHTS.}

In order to be able to trace its historical beginnings, we need a clear and applicable scheme of what ethics of dignity and rights are like. In this section I wish to propose such a working definition, based on contemporary research and theoretical work on the themes on Imago Dei and of human rights. ${ }^{16}$ An ethics of dignity and rights (henceforth ED\&R) is not a school of ethics in the line of "virtue ethics" or Kantian ethics. It professes no meta-ethical claims. ${ }^{17}$ Hence, it does not take positions in debates such as the primacy of rights vs. the primacy of duties. Nor does it pretend to cover all of ethics and its concerns. ED\&R is an instrument of thinking and conceptualization which may also serve as a template for legislation.

\section{A. Patient Centered Ethics.}

ED\&R is an instrument that focuses on the recipient of action (or inaction). ED\&R lays moral claims on agents, institutions etc. Rights stem solely from a predicament of a right bearer. ${ }^{18}$ The moral claims generated by rights may vary depending on the circumstances and the relationship and power between the right bearer and other persons and institutions. A man stranded on a deserted island finds his right to life in jeopardy. Yet, in the absence of any human agency even aware of his existence, the use of "right" in a context that cannot generate any moral claim is futile.

\section{B. Natural.}

Human dignity and rights exist even without the presence of any positive legislation endowing them to anybody. Acts of legislation and endowment may confer legal rights reflecting and refining human rights. But the dignity and rights of people are recognizable, not created. ${ }^{19}$ Strong naturalism denies the legitimacy of any positive legislation that violates human rights. ${ }^{20}$

\section{Comprehensive Substantiality.}

ED\&R covers a wide array of very basic human needs and values. People might disagree whether certain goods should be considered rights. The debate on the so- called right to have children is a case in point. However, within the frameworks of ED\&R, regarding a certain good as a very basic human good necessitates its consideration as a right, and its deprivation counts as offensive to human dignity.

\section{Universality.}

\footnotetext{
${ }^{15}$ Another explanation is related to the Augustine's descendant doctrine. See my paper on Lactantius (cited below).

${ }^{16}$ In addition to all the sources cited in this article, I would point out E. Bloch, Natural Law and Human Dignity (Cambridge, MA: MIT Press, 1987); J. Mahoney, The Challenge of Human Rights: Origins, Development and Significance (Oxford, Blackwell, 2007).

${ }^{17}$ This assertion does not rule out the possibility of a complete system of ethics based on the notion of rights, such as propositioned by Alan Gewirth.

${ }^{18}$ The patients of human rights are only individual human beings. It is often held that "human dignity" sets limits on conduct in the protection of society's sense of respect for human dignity.

${ }^{19}$ S. Darwell, "Two Kinds of Respect" Ethics 88 (1977): 43-9.

${ }^{20}$ C. Santiago-Nino, The Ethics of Human Rights (Oxford, Clarendon, 1991).
} 
Human rights apply to all humans, "ergo omnes". No other personal quality or standard of behavior are necessary for being dignified as human. The universality of human dignity and rights does not necessarily sanction either the exploitation of animals or unlimited liberty in our conduct towards non-human entities. As a matter of fact ED\&R does not have to say anything metaphysical or moral about the non-human world. The element of universality implies equality in respect to human dignity and rights. People might differ from each other by natural endowments, legal status and numerous other standards. Some people behave shamefully while others deserve praise for their "dignified" comportment. However, no one person bears more "human dignity" as such than any other. $^{21}$

Witnessing one's wife and a stranger drowning simultaneously, a man may choose to save his wife, not the stranger. This does not assert that the wife's right to life is stronger to the stranger's. Indeed, precisely because of the absolute equality of all humans with regard to their dignity and right to life, resolution of such tragic conflicts calls upon moral considerations outside the realm of dignity and rights, considerations of care and responsibility for one's kin, for example. ${ }^{22}$

\section{E. Bi-layered structure.}

It is widely accepted that rights are "master moral concepts" that prima facie trump over other moral and non-moral considerations. When a right and a non-right value are in conflict, rights almost always predominate. This is the very essence of "moral rights." ${ }^{23}$ This implies a division of morality into two levels (the bi-layered structure). Rights reside on a privileged level, exercising an overriding power over non-rights moral values in an ordinary level. In order to illustrate the point, let's think of a neighbor dumping his trash in my back yard. It would be logically cogent to say that the neighbor violates my rights to property and privacy. But it would sound somewhat odd as well. Rights are too powerful and too elaborate concepts to be invoked in the face of merely rude and intrusive behavior. On the other hand, if the city authorities decide to use my own property as a depository for toxic waste, it would be appropriate to object on the grounds of my rights to property. In such situations we call upon our rights (=the trumping layer) because we acknowledge the legitimacy of civil authorities to make tough decisions regarding the disposal of waste, and the moral need to protect a large population, as well as the natural environment for noxious fumes (the ordinary layer).$^{24}$

In sum, ED\&R is a patient-centered instrument of ethics, realizable within different schools of ethics. ED\&R is about recognition of the moral calling associated with very basic human goods by offering them a protective and promotive layer of moral claims with an overriding power over other interests and values in nearly all of real-life circumstances. ED\&R targets all human beings as such and without discrimination.

Rights are most useful in situations of conflict among values, only one of which is a right. Most typically rights are invoked in conflicts between the common good and private interests. Rights are philosophically redundant in conflicts between moral values and other interests and values. For example, ED\&R is not necessary logically in order to condemn sexual harassment at work or clandestine HIV testing of patients. The invocation of dignity and rights in such cases is meant to underscore the severity of the offense and to recruit the widest and strongest support against it. ${ }^{25}$ Rights generate bitter controversies in conflicts among different rights and among different elements constituting rights (e.g. when an autonomous choice collides with the value of life). ${ }^{26}$

${ }^{21}$ D. Beyleveld and R. Brownswod, Human Dignity in Bioethics and Biolaw. (Oxford, Oxford University Press, 2001), $50 \mathrm{ff.}$

${ }^{22}$ B. Williams, "Persons, Character and Morality" in The Identities of Persons, ed. A. O. Rorty (Berkeley: University of California Press, 1976), 197-216; T. Nagel, Other Minds: Critical Essays 1969-1994. (New York: Oxford University Press, 1995), 167-73. In the same vein, we sometimes resort to utilitarian considerations in order to settle moral dilemmas. When faced with a choice between a course of action that saves one person and a course of action that saves seven, the latter seems to be morally preferable even in strict Kantian terms. See T. E. Hill, "Humanity as Ends in Itself" Ethics 91 (1980): 95; Y. Barilan, "Towards a Dialogue between Utilitarianism and Medicine" Medicine Healthcare \& Philosophy 7 (2004): 16373.

${ }^{23}$ R. Dworkin, "Rights as Trumps" in Theories of Rights ed. J. Waldron (Oxford: Oxford University Press, 1984); M. A. Warren, Moral Status: Obligations to Persons and Other Living Things (Oxford: Oxford University Press, 1997).

${ }^{24}$ This argument is a response to Pogge. I also differ from his definition of "human rights" by not including the "broadly sharable" criterion. Nondiscrimination on the basis of sex, gender and sexual orientation is considered a human right although it is not "broadly sharable". As a matter of fact it was not acknowledged at all until very recently. See T. Pogge, World Poverty and Human Rights (Cambridge, UK: Polity Press, 2002 ), Ch. 2.

${ }^{25}$ This is borne out, for example, by Turkey's reclassification of sexual harassment as a violation of women's rights rather than an offence against society, the family and morality. This seemingly technical alteration is considered a breakthrough in women's status. See "Sex and Power in Turkey: Feminism, Islam and the Maturing of Turkish Democracy" (2007) European Stability Institute, Berlin, Germany and Istanbul, Turkey, https://www.esiweb.org/pdf/esi_document_id_90.pdf

${ }^{26}$ Y. Barilan and M. Brusa, "Bioethics and Human Rights" Journal of Medical Ethics. Forthcoming. 


\section{THE BEGINNING OF ETHICS OF DIGNITY AND RIGHTS AND ITS CONTEMPORARY CHALLENGES.}

In another body of research, I argued that the first to offer an ethics of rights and dignity was the Christian philosopher Lactantius (4th cent.). In his book The Divine Institutions we find for the first time an elaborate description of inter-personal morality and political theory fashioning all of the elements numerated above. ${ }^{27}$ Lactantius was the only author - Jewish or Christian - who construed our inter-personal duties on the maxim "man is the image of God," asserting the right of every person to a decent share of vital goods and the immorality of slavery, war and Capital punishment. ${ }^{28}$ Lactantius' moral theory is the first in history explicating "The Christian conception of the dignity of man and of the misery of man is all of one piece."29

Lactantius also argued for religious tolerance, realizing that when human dignity is not disrespected (the trump layer) there is also an opening for tolerance of otherwise controversial conduct (the ordinary layer)..$^{30}$ Thirteen hundred years will pass until the revival of an ethics of dignity and rights by John Locke. This modern ethos of dignity and rights differs from Lactantius' by laying much less emphasis on the rights to decent share of vital goods and stressing much more the negative rights to liberties such as free speech and privacy.

From its very beginnings, the modern human rights movement has been divided between an "interest" version and a "will" version of dignity and rights. According to the interest version, human rights protect basic and inalienable rational human interests such as life and health. According to the "will" version, rights protect domains of free will, in which the personal autonomy of the right holder reigns supreme. For example, in the context of the right to the integrity of the person, a "will" theorist of rights would accept autonomous decisions either to protect the natural integrity of the body or to manipulate it at will. Will theorists are less inclined to resort to the word "dignity," but it is evident that in their eyes not only do frustration of autonomous choices regarding one's own body harm one's sense of self respect, but also one's dignity as a person..$^{31}$

Contemporary bioethics has focused much attention on the question of human identity and human boundaries - the moral status and the dignity and right-bearing status of so-called "marginal cases," such as embryos, the irreversibly comatose and intelligent apes. Understanding of the different historical narratives of human dignity may help us grasp differences in the broader conceptualization of "the human", its "basic needs" as well as "human rationality." For example, the Jewish tradition underlines the sexual human body shape as the locus of Imago Dei, and inventiveness and creativity as its manifestations. In this light, virtually all rabbinic authorities find medical embryonic stem cell research as promoting the value of Imago Dei. ${ }^{32}$ In the same vein, the Chief Rabbinate of Israel and leading rabbis endorse therapeutic as well as procreative cloning of humans. ${ }^{33}$

The special power of an ethics of dignity and rights lies in its universal appeal and coverage of basic human needs and in respect for human individuals as rational, autonomous and vulnerable. Whereas controversies such as on stem-cell research bring to light profound difference in cultural constructions of human dignity, the divergent meta-narratives of dignity and rights reinforce each other's appeal with regard to substantially more pressing problems such as world poverty, inequalities in health and education and the abuse of humans and their environment.

The ethics of dignity and rights is a politically ambitious enterprise, but a philosophically humble one. It does not strive to answer many ethical and meta-ethical questions and dilemmas. Hence, it is receptive to accommodate different ethical theories and multicultural deliberations. Indeed, one of its most important achievements is the recruitment of commitments to urgent human concerns from a broad array of very different and even rival world-views. The prominence of "human dignity and rights" in contemporary international politics and discourse does not bridge many important variations of "dignity and rights," but it offers a common ground for addressing the world's most pressing crises of poverty, oppression, ill-health and discrimination.

\footnotetext{
${ }^{27}$ See "On the Divine Institutions," Book 6, Ch. 10-11, Christian Classic Ethereal Library, http://www.ccel.org/ccel/schaff/anf07.iii.ii.vi.x.html; Y. Barilan, "Lactantius and Global Bioethics based on Dignity and Rights." Forthcoming.

${ }^{28}$ Lactantius revised his own view on war in his later writings. See J. I. Campbell, "The Angry God: Epicurus, Lactantius and Warfare" in Epicurus: His Continuing Influence and Contemporary Relevance, eds. D. R. Gordon and D. B. Suits (Rochester, NY: RITS Graphic Arts, 2005), 45-68.

${ }^{29}$ R. Niebuhr, The Essential Reinhold Niebuhr: Selected Essays and Addresses (New Haven, CT: Yale University Press, 1987), 223. To the best of my knowledge, neither here nor anywhere else in his writing does Niebuhr discuss Lactantius and his ethics.

${ }^{30}$ Lactantius was arguing for toleration of Christianity when Christians were considered traitors and were harshly prosecuted.

${ }^{31}$ M. H. Kramer and N. E. Simmonds, and H. Steiner, A Debate Over Rights: Philosophical Enquiries (Oxford: Clarendon,1998).

${ }^{32}$ Barilan and Siegal.

${ }^{33}$ Y. Barilan, "The Debate on Cloning: Some Contributions from the Jewish Tradition" in Cloning: A Multicultural Perspective, eds., H. Roetz and C. Frey (London: Rodopi, 2005): 311-314.
} 


\section{REFERENCES}

Barilan, Y. "Lactantius and Global Bioethics based on Dignity and Rights." Forthcoming.

Barilan, Y. "The Debate on Cloning: Some Contributions from the Jewish Tradition" in Cloning: A Multicultural Perspective, edited by H. Roetz and C. Frey (London: Rodopi, 2005): 311-314.

Barilan, Y. "Towards a Dialogue between Utilitarianism and Medicine" Medicine Healthcare \& Philosophy 7 (2004): 163-73.

Barilan Y., and M. Brusa, "Bioethics and Human Rights" Journal of Medical Ethics. Forthcoming.

Barilan, Y, and G. Siegal, "Stem Cell Research: an Israeli Perspective" In Crossing Borders: Cultural, Religious and Political Differences concerning Stem Cell Research, edited by Bender, Hauskeller, Manzei (Münster, Germany: Agenda Verlag, 2005).

Beyleveld D., and R. Brownswod, Human Dignity in Bioethics and Biolaw (Oxford, Oxford University Press, 2001).

Bloch, E. Natural Law and Human Dignity (Cambridge, MA: MIT Press, 1987)

Campbell, J. I. "The Angry God: Epicurus, Lactantius and Warfare" in Epicurus: His Continuing Influence and Contemporary Relevance, edited by D. R. Gordon and D. B. Suits (Rochester, NY: RITS Graphic Arts, 2005).

Christian Classic Ethereal Library. On the Divine Institutions. http://www.ccel.org/ccel/schaff/anf07.iii.ii.vi. x.html

Darwell, S. “Two Kinds of Respect” Ethics 88 (1977): 43-9.

Dworkin, R. "Rights as Trumps" in Theories of Rights, edited by J. Waldron (Oxford: Oxford University Press, 1984)

European Stability Institute. "Sex and Power in Turkey: Feminism, Islam and the Maturing of Turkish Democracy” (2007), Berlin, Germany and Istanbul, Turkey, https://www.esiweb.org/pdf/esi_document_id_90.pdf

Finnis, J. Aquinas: Moral, Political and Legal Theory (Oxford: Oxford University Press, 1998).

Garnsey, P. Ideas of Slavery from Aristotle to Augustine, (Cambridge: Cambridge University Press, 1996).

Goodman, L. E. Judaism, Human Rights and Human Values. (Oxford: Oxford University Press, 1998).

Greenberg, M. Studies in the Bible and Jewish Thought. (Philadelphia, PA: Jewish Publication Society, 1995).

Häyry, M. “Another Look at Dignity,” Cambridge Quarterly of Healthcare Ethics 13 (2004): 7-14.

Hill, T. E. "Humanity as Ends in Itself" Ethics 91 (1980): 95

Jackelen, A. "The Image of God as Techno Sapiense," Zygon 37 (2002): 289 - 302

Kramer, M. H., and N. E. Simmonds, and H. Steiner, A Debate Over Rights: Philosophical Enquiries (Oxford: Clarendon, 1998).

Mahoney, J. The Challenge of Human Rights: Origins, Development and Significance (Oxford, Blackwell, 2007).

Mary, M. "Slavery in the Writings of St. Augustine" The Classical Journal 49 (1954): 363-8

Nagel, T. Other Minds: Critical Essays 1969-1994. (New York: Oxford University Press, 1995).

Niebuhr, R. The Essential Reinhold Niebuhr: Selected Essays and Addresses (New Haven, CT: Yale University Press, 1987).

Niebuhr, R. The Nature and Destiny of Man: a Christian Interpretation: Human Nature (New York: Charles Scribner \& Sons, 1951).

Novak, D. "Is There a Concept of Individual Right in Jewish Law?" Jewish Law Association Studies 7 (1994): 129-52.

Pogge, T. World Poverty and Human Rights (Cambridge, UK: Polity Press, 2002).

Pope John Paul VI, "Encyclical Letter: On the Development of Peoples" (1967), http://www.ewtn.com/library/ encyc/p6develo.htm

Pope Leo III. "Encyclical Letter: On Capital and Labor." http://w2.vatican.va/content/leo-xiii/en/encyclicals /documents/hf_l-xiii_enc_15051891_rerum-novarum.html

Rousseau, R. W. Human Dignity and the Common Good (Westport, CT: Greenwood Press, 2002).

Santiago-Nino, C. The Ethics of Human Rights (Oxford, Clarendon, 1991).

Sigismund, P. E. "Law and Politics" In The Cambridge Companion to Aquinas, edited by N. Kretzman and E. Stump, (Cambridge: Cambridge University Press, 2003). 
Soulen, R. K., and L. Woodhead, "The Introduction" in God and Human Dignity, Soulen and Woodhead, H. Roetz and C. Frey, eds. (Grand Rapids, MI: Eerdmans, 2006).

The Vatican. Catechism of the Catholic Church, No. 1700.

Warren, M. A. Warren, Moral Status: Obligations to Persons and Other Living Things (Oxford: Oxford University Press, 1997).

Williams, B. "Persons, Character and Morality" in The Identities of Persons, edited by A. O. Rorty (Berkeley: University of California Press, 1976). 